\title{
НОВІ ТЕХНОЛОГІЇ ОРГАНІЗАЦІї ВИВЧЕННЯ \\ МОРФОФУНКЦІОНАЛЬНИХ ДИСЦИПЛІН У ВИЩИХ НАВЧАЛЬНИХ ЗАКЛАДАХ І-ІІ РІВНІВ АКРЕДИТАЦІї ЯК ПІДГОТОВКА ДО ВПРОВАДЖЕННЯ КРЕДИТНО-МОДУЛЬНОЇ СИСТЕМИ ОСВІТИ НА ВІДПОВІДНИХ КАФЕДРАХ ВИЩИХ НАВЧАЛЬНИХ ЗАКЛАДІВ III-IV РІВНІВ АКРЕДИТАЦІЇ
}

Ю. Ф. Педанов, А. І. Гоженко

Одеське обласне базове медичне училище, Одеський НДУ медицини транспорту МОЗ Украӥни

\section{NEW METHODS OF ORGANIZATION OF MORPHO-FUNCTIONAL SUBJECTS LEARNING IN THE INSTITUTIONS OF HIGHER EDUCATION OF THE I - II LEVEL OF ACCREDITATION AS PREPARATION FOR THE IMPLEMENTATION OF CREDIT-MODULAR SYSTEM OF EDUCATION ON THE CORRESPONDING CHAIRS OF THE INSTITUTIONS OF III-IV LEVELS OF ACCREDITATION}

\author{
Yu. F. Pedanov, A. I. Hozhenko \\ Odesa Regional Base Medical College, \\ Odesa Ukrainian Research Institute for Medicine of Transport of MPH of Ukraine
}

\begin{abstract}
У статті висвітлено особливості створення навчальних планів для підготовки 3 дисциплін “Анатомія і фізіологія людини" та "Патологія" у ВНЗ I-II та III-IV рівнів акредитації.

In the article the author discusses peculiarities of curricula formation for training on the subjects "Human Anatomy and Physiology" and "Pathology" in the institutions for professional learning of the I-II and III-IV levels of accreditation.
\end{abstract}

Вступ. Підготовка нового покоління висококваліфікованих медичних працівників не можлива без впровадження інноваційних технологій та форм організації навчального процесу з урахуванням традицій вітчизняної медичної освіти та процесу інтеграції до Європейського освітнього простору.

Концепцією розвитку вищої медичної освіти в Україні передбачено виконання системи заходів, спрямованих на підвищення якості підготовки фахівцівмедиків, інтеграцію медичної освіти і науки, вирішення кадрових проблем у галузі, забезпечення конкурентоспроможності випускників на вітчизняному та міжнародному ринках праці [1].

3 метою оптимального забезпечення молодшими медичними спеціалістами пріоритетним напрямком реформування вищої медичної освіти $є$ комплексне вирішення методичних питань у ВНЗ I-II рівнів акредитації, з урахуванням іноземного і збереженням власного позитивного досвіду, оскільки цей етап можна розглядати як підготовку до навчання у ВНЗ IIIIV рівнів акредитації [2].

Основна частина. Модернізація освітянського простору має на меті приведення навчальних програм до єдиного стандарту. Найбільш важливим є вивчення доцільності створення та використання нових програм, їх змін і організація навчального процесу з визначенням місця кожної дисципліни у системі міжнародних стандартів.

Впровадження євростандартів потребує, перш за все, зрозумілої назви дисциплін. Підготовка фахівців для галузі охорони здоров'я здійснюється у ВНЗ IIV рівнів акредитації: серед них 44 медичних училища, 69 медичних коледжів, 2 інститути медсестринства. Контингент студентів ВНЗ I-II рівнів акредитації становить більш 70 тисяч осіб. На нашу думку, доцільна назва і вивчення інтегрованих дисциплін

() Ю. Ф. Педанов, А. І. Гоженко 
“Анатомія і фізіологія” та "Патологія”, що відповідає світовим нормам.

Запропоновані окремі програми 2011 р. двох дисциплін “Анатомія людини” та “Фізіологія” неможливо одночасно вивчати протягом одного навчального року, тому що виникає неузгодженість тем, пропонуються проведення експериментів, які неможливо проводити на тваринах з етичних міркувань, а також внаслідок відсутності спеціальної апаратури. Дослідження фізіологічних функцій людини можливо тільки при наявності кабінету функціональної діагностики, лабораторії і в умовах клініки. Не кожний ВНЗ I-II рівня акредитації може це забезпечити за умов обмеженого фінансування. Тому в медичних училищах і коледжах Європи і США вивчається інтегрована дисципліна “Анатомія і фізіологія”, і якщо ми бажаємо увійти в світовий простір, то необхідно звернути на це увагу. До речі, про вивчення анатомії і фізіології висловлювалися видатні вітчизняні вчені ще в 18-19 сторіччях, професори М. Х. Пеккен, М. І. Шеін, П. А. Загорський, І. В. Буяльський, В. І. Таренецький, Є. О. Мухін, М. І. Пирогов, А. Філомафітський, А. Вальтер та ін. Тому фактично вивчали анатомічну фізіологію і фізіологічну анатомію $[3,4]$.

Це не стосується медичних університетів, де потужні кафедри анатомії, фізіології, патоморфологіі, патофізіології, де студенти послідовно вивчають дисципліни на різних семестрах, курсах. Перед ними стоять питання більшого об' єму та глибини вивчення, необхідні для майбутнього лікаря.

У навчальних планах необхідно додержуватись того принципу, що більшість теоретичних занять, які підкріплюються практичними, з “Анатомії і фізіології” передують вивченню дисципліни “Патологія”. При цьому необхідна адекватна кількість практичних годин.

Згідно з наказом МО3 України № 100 - Адм. від 13.04.2007 р. необхідно більше залучати для складання програм та навчальних планів викладачів-ме-

\section{Література}

1. Про затвердження Концепції розвитку вищої медичної освіти в Україні : наказ МОЗ та АМН України №522/51 від 12.09.2008p.

2. Сучасний стан кадрової політики у галузі охорони здоров'я / 3. М. Митник, М. В. Банчук, І. І. Фещенко [та ін.] // Впровадження кредитно-модульної системи організації навчального процесу у ВМ(ф)НЗ України : результати, проблеми та перспективи : матер. Навч.-наук.конф. - Тернопіль, 2010. - С. 3-5.

3. Педанов Ю. Ф. Практическое пособие по анатомии и физиологии человека / Ю. Ф. Педанов ; под. ред. тодистів опорної циклової комісії з дисциплін природничо-наукової підготовки.

Програми повинні бути дійсно новими, а не переписувати існуючі підручники.

Нами запропоновано програми, на що є Свідоцтво про реєстрацію авторського права. Це знайшло відображення в посібниках "Практичний посібник з анатомії і фізіології людини” (2008) і “Практичний посібник з патології' (2009). Більш того, вони перекладені на англійську мову $[5,6,7]$.

Необхідно збільшити міждисциплінні зв' язки.

Перш за все це стосується дисципліни “Фармакологія”, яку необхідно вивчати одночасно з дисципліною “Анатомія і фізіологія людини” та "Патологія” $і$ наприкінці року складати іспит.

Необхідно приділяти більше уваги вивченню англійської мови із застосуванням перекладених нами посібників 3 “Анатомії і фізіології людини” і “Патологіï”.

Висновки. Оскільки навчання у ВНЗ III-IV рівнів акредитації здійснюється за кредитно-модульною системою, необхідні:

1) модернізація програм і навчальних планів для вивчення у ВНЗ I-II рівнів акредитації інтегрованих дисциплін “Анатомія і фізіологія людини” та "Патологія";

2) збереження принципів морфофункціональності та нейрогуморальної регуляції функцій органів, систем, організму в цілому;

3) максимальне наближення досліджень до клініки;

4) поліпшення міждисциплінної інтеграції, в тому числі з фармакологією та іноземними мовами;

5) розробити оригінальну універсальну програму інтегрованих дисциплін “Анатомія і фізіологія людини” та "Патологія" для базисних спеціальностей “Лікувальна справа”, “Акушерська справа”, “Сестринська справа” з оптимальною кількістю годин навчального плану.

А. И. Гоженко. - Одесса : Астропринт, 2008. - 52 с.

4. Педанов Ю. Ф. Практическое пособие по патологии / Ю. Ф. Педанов ; под ред. А. И. Гоженко. - Одесса : Астропринт, 2009. - $36 \mathrm{c}$.

5. Педанов Ю. Ф. Алгоритми засвоєння знань і практичних навичок у системі морфофункціональних наук у вузах І-ІІ рівнів акредитації / Ю. Ф. Педанов, Р. Ф. Макулькін, А. І. Даниленко // Мед. освіта. - 2003. - № 1. -С. 18-21.

6. Анатомия тканей, костей, сочленений, мускулов и фасций человеческого тела изданіх А. Вальтером, доктором медицины, о. профессором физиологической анато- 
мии и микрографии при Императорском университете Св. Владимира и врачем при хирургическом отделении Киевского городского госпиталя. - К., 1853. - 550 с.

7. Физиология, изданная для руководства своих слушателей Алексеем Филомафитским, медицины доктором,
Императорского московского университета о. профессором физиологии и общей патологии, и обществ естествоиспытателей природы и физико-медицинского членом. M., 1840.-256 c. 